\title{
KEADILAN GENDER DALAM PENDIDIKAN ISLAM DI PONDOK PESANTREN
}

\section{Sumaryati}

Sekolah Tinggi Agama Islam (STAI) Darussalam Lampung

Desa Labuhan Ratu Satu, Way Jepara, Kabupaten Lampung Timur, Lampung

Email: sumaryati_salim35@yahoo.com

\begin{tabular}{|c|c|c|}
\hline Diterima: & Revisi: & Disetujui: \\
20 September 2018 & 23 Oktober 2018 & 11 Desember 2018 \\
\hline
\end{tabular}

\begin{abstract}
This paper describes gender justice in Islamic education in Islamic boarding schools that has not been done optimally. This is due to cultural constraints which have resulted in a less gender responsive policy, namely the patriarchal system. In the patriarchal system men control women's work. The implication is that santri occupy the main authority in the pesantren environment. In analyzing the nature and culture theory, women and their functions are identified with "life", placing themselves close to nature. While men are placed as a group entitled to fill the public sector. In boarding schools, generally still treat santri with the dichotomy of the role. As a result santri have limited access to activities outside the pesantren. Subordination to students is also evident from the lack of opportunities to appear in public. Because something that is mass and prestigious is considered a male area. Finally, the experience gained by the santriwan was greater. The impact of the provision received by students for preparation for plunge in the community is not as big as santriwan.
\end{abstract}

Keyword: gender justice, education, and Islamic boarding schools

\begin{abstract}
Abstrak
Tulisan ini mendeskripsikan tentang keadilan gender dalam pendidikan Islam di pondok pesantren belum dilakukan secara optimal. Hal ini disebabkan dalam kendala kultural yang mengakibatkan adanya kebijakan kurang responsif gender, yakni sistem patriarki. Pada sistem patriarki laki-laki mengontrol kerja perempuan. Implikasinya santriwan menempati otoritas utama di lingkungan pesantren. Dalam analisa teori nature dan culture, perempuan dan fungsinya diidentikkan dengan "kehidupan", menempatkan dirinya dekat dengan alam. Sedangkan laki-laki di tempatkan sebagai kelompok yang berhak mengisi sektor publik. Di pesantren, umumnya masih memperlakukan santrinya dengan dikotomi peran tersebut. Akibatnya
\end{abstract}


santriwati mempunyai akses terbatas untuk mengikuti kegiatan di luar pesantren. Subordinasi pada santriwati juga terlihat dari minimnya kesempatan untuk tampil di depan umum. Karena sesuatu yang massal dan bergengsi dianggap sebagai wilayah laki-laki. Akhirnya pengalaman yang didapat santriwan lebih banyak. Dampaknya bekal yang diterima santriwati untuk persiapan terjun ditengah masyarakat tidak sebesar santriwan.

Kata Kunci: keadilan gender, pendidikan, dan pesantren

\section{A. Pendahuluan}

Pemerintah Indonesia telah melakukan upaya kongkrit dalam mengatasi ketidakadilan gender melalui kebijakan pengarusutamaan gender (PUG) yang dikenal sebagai Inpres No. 9 Tahun 2000. Sejumlah undang-undang dan peraturan pemerintah ditetapkan sebagai instrumennya, tetapi lebih dari itu adalah diperlukan dukungan riil dari masyarakat agar tujuan PUG dalam mewujudkan masyarakat yang berkesetaraan dan berkeadilan gender untuk mencapai kesejahteraan sosial dapat tercapai. ${ }^{1}$

Pengarusutamaan gender dalam pembangunan nasional salah satunya dilakukan pada lembaga pendidikan dimana hal ini merupakan kebijakan implementatif. Melalui peraturan Menteri Dalam Negeri Nomor 15 tahun 2008 tentang pedoman umum pengarusutamaan gender di daerah dan peraturan menteri pendidikan nasional No. 84 tahun 2008 tentang pedoman pelaksanaan pengarusutamaan gender bidang pendidikan, maka keterlaksanaannya pada semua lembaga formal merupakan keharusan, termasuk pondok pesantren. Maka pesantren dituntut untuk melakukan re-desaign kurikulum pengajaran, menjadi wacana pembelajaran gender social inclusion, yaitu pembelajaran yang mengakui dan mempertimbangkan perbedaan kebutuhan, minat, pengalaman, dan cara belajar peserta didik yang disebabkan oleh konstruksi sosial pada lingkungannya. Kesetaraan dan keadilan gender menghendaki agar laki-laki maupun perempuan memiliki kesempatan dan partisipasi yang sama dalam

${ }^{1}$ Mufidah, Gender di Pesantren Salaf Why Not? (Malang: UIN-Maliki Press, 
proses pendidikan, memiliki kontrol atau wewenang yang seimbang atas sumber daya, dan mendapatkan manfaat hasil pendidikan secara merata.

Implementasi PUG dalam bidang pendidikan tidak berdiri sendiri dan terpisah dari keseluruhan program, namun PUG di integrasikan ke dalam strategi pendidikan yang ada, terpadu dan meresap kedalam empat fungsi utama manajemen mutu pendidikan yaitu: perencanaan, pelaksanaan, pemantauan dan evaluasi. Terbitnya Instruksi Presiden RI No. 09 tahun 2000 tentang pengarusutamaan gender (PUG) dalam pembangunan nasional menjadi salah satu kebijakan yang sangat penting untuk mewujudkan tujuan pembangunan tersebut.

Pondok pesantren merupakan Pusat Pendidikan Islam, dakwah, dan pengabdian masyarakat tertua di Indonesia. Lembaga ini dikenal memiliki sistem pendidikan dengan ciri-ciri dan karakteristik yang khas. Keberadaan pondok pesantren sampai sekarang masih berdiri kokoh di tengah-tengah masyarakat, dengan menampakkan kebhinekaan dan kemandirian, seiring dengan perkembangan Islam di Indonesia. Meski demikian, besarnya kontribusi pondok pesantren dalam pengembangan ajaran Islam di Indonesia menyisakan satu problem mendasar, yaitu terkait dengan isu kesetaraan dan gender. Hal ini terlihat pada adanya kesenjangan akses, partisipasi, peran, dan tanggung jawab yang dimiliki santriwan dan santriwati, baik pada aspek pengambilan kebijakan, sistem manajerial, pembelajaran, bahan ajar, dan pemanfaatan fasilitas yang tersedia. Akibatnya, output santriwan memiliki potensi lebih besar untuk memainkan peran di tengah-tengah masyarakat.

Kesenjangan tersebut juga berdampak pada kelangkaan ulama' perempuan yang kontribusinya justru sangat dibutuhkan, terutama dalam upaya peningkatan pemberdayaan perempuan untuk mencapai Millenium Development Goals dan untuk mengatasi isu-isu gender khususnya di kalangan masyarakat muslim. ${ }^{2}$ Pengarus-

2 Mufidah, Gender di Pesantren Salaf Why Not ?... h.2 
utamman gender wajib di implementasikan dalam berbagai bidang salah satunya bidang pendidikan termasuk pondok pesantren. Dimana pondok pesantren identik dengan pemeliharaan doktrin agama yang kuat. Dengan adanya realita tersebut, perlu diketahui bagaimana bentuk-bentuk implementasi keadilan gender dalam pendidikan Islam di pondok pesantren.

\section{B. Gender dan Beberapa Konsepnya}

Menurut Mosse gender adalah seperangkat peran yang seperti halnya kostum dan topeng di teater, menyampaikan kepada orang lain bahwa kita adalah feminin atau maskulin. Perangkat perilaku khusus ini yang mencakup penampilan, pakaian, sikap, kepribadian, bekerja di dalam dan luar rumah tangga, seksualitas, tanggung jawab keluarga dan sebagainya secara bersama-sama memoles peran gender. ${ }^{3}$

Sherry B Ortner menyatakan bahwa: "woman's body and its functions, more involved more of the time with "species life", seem to place her closer to nature, in contrast to man's physiology, which frees him more completely to take up the projects of culture". ${ }^{4}$ Maksudnya bahwa tubuh perempuan dan fungsinya lebih cenderung dengan "kehidupan", menempatkan dirinya dekat dengan alam, berbeda dengan laki-laki yang sepenuhnya bebas dengan proyek budaya. Memperhatikan hal tersebut, perempuan selalu diidentikkan dengan kehidupan. Ia memiliki rahim, di dalam rahim tersebutlah sebuah kehidupan baru mulai terbentuk dan tumbuh.

Sherry B. Ortner juga mengemukakan bahwa tubuh perempuan yang lebih hebat dengan fungsi alam sekitar reproduksi, ia lebih dipandang sebagai bagian dari alam daripada pria. "Because of woman's greater bodily involvement with the natural functions surrounding reproduction, she is seen as more a part of nature than is

3 Mosse, J.C, Gender \& Pembangunan, (Yogyakarta: Pustaka Pelajar. 2007) h. 2

4 Sherry B Ortner, Woman, Culture, and Society, (Stanford, CA: Stanford University Press, 1974), h. 73 
man". ${ }^{5}$ Menurut Ortner, karena laki-laki tidak memiliki "natural" dasar untuk orientasi keluarga, maka mereka membuat "natural" milik lakilaki yaitu agama, ritual, politik, dan lain-lain. Tidak hanya dengan "culture", laki-laki juga diidentifikasikan dengan kreativitas sebagai lawan dari "nature".

Berdasarkan dari berbagai definisi di atas yang dikemukakan ahli, maka dapat disimpulkan persamaan bahwa gender merupakan suatu konstruksi atau bentuk sosial yang sebenarnya bukan bawaan lahir sehingga dapat dibentuk atau diubah tergantung dari tempat, waktu, zaman, suku, ras, bangsa, budaya, status sosial, pemahaman agama, negara, ideologi, politik, hukum, dan ekonomi.

\section{Konsep Ketidakadilan Gender}

Kondisi saat ini menunjukkan bahwa perbedaan jenis kelamin dapat menimbulkan perbedaan gender (gender differences) dimana kaum perempuan itu tidak rasional, emosional, dan lemah lembut, sedangkan laki-laki memiliki sifat rasional, kuat atau perkasa. Perbedaan gender (gender differences) sebenarnya bukan suatu masalah sepanjang tidak menimbulkan ketidakadilan gender (gender inequalities). Namun, yang menjadi masalah ternyata gender difference ini telah menimbulkan berbagai ketidakadilan, baik bagi kaum lakilaki dan utamanya terhadap kaum perempuan. Secara biologis (kodrat) kaum perempuan dengan organ reproduksinya dapat hamil, melahirkan dan menyusui, kemudian muncul peran gender (gender role) sebagai perawat, pengasuh, dan pendidik anak. Dengan demikian, gender role dianggap tidak menimbulkan masalah dan tidak perlu digugat. Namun, yang menjadi masalah dan perlu dipertanyakan adalah struktur gender inequalities yang ditimbulkan oleh gender role dan gender differences. ${ }^{6}$

Adapun bentuk-bentuk ketidakadilan tersebut dapat dilihat sebagai berikut:

${ }^{5}$ Sherry B Ortner, Woman, culture, and society... h. 76 (2008), h. 9

6 Rian Nugroho, Gender dan Strategi Pengarus-utamaannya di Indonesia. 
a. Marginalisasi.

Menurut Djunaedi marginalisasi merupakan menempatkan seseorang karena jenis kelaminnya sebagai pihak yang tidak dianggap penting dalam faktor ekonomi, sekalipun perannya sangat krusial. ${ }^{7}$

b. Subordinasi.

Menurut Nugroho subordinasi timbul sebagai akibat pandangan gender terhadap kaum perempuan. Sikap yang menempatkan perempuan pada posisi yang tidak penting muncul dari adanya anggapan bahwa perempuan itu emosional, atau irasional sehingga perempuan tidak bisa tampil memimpin. ${ }^{8}$

c. Stereotipe.

Stereotipe merupakan pelabelan atau penandaan negatif terhadap kelompok atau jenis kelamin tertentu. Salah satu contoh pelabelan terhadap perempaun adalah pandangan bahwa perempuan adalah makhluk yang rawan sehingga harus dijaga dan dibatasi, agar tidak terkena gangguan sampai pada saatnya menikah.

d. Violence.

Menurut Nugroho violence atau kekerasan merupakan invasi atau serangan terhadap fisik maupun integritas mental psikologis seseorang yang dilakukan terhadap jenis kelamin tertentu, umumnya perempuan sebagai akibat dari perbedaan gender. ${ }^{9}$

e. Beban Ganda.

Menurut Fakih adanya anggapan bahwa kaum perempuan memiliki sifat memelihara dan rajin, serta tidak cocok untuk menjadi kepala rumah tangga, berakibat bahwa semua pekerjaan domestik rumah tangga menjadi tanggung jawab kaum

7 Wawan Djunaedi, Pendidikan Islam Adil Gender di Madrasah, (Jakarta: Pustaka STAINU, 2008), h. 17

${ }^{8}$ Rian Nugroho, Gender dan Strategi Pengarus-utamaannya di Indonesia..., h. 11

${ }^{9}$ Rian Nugroho, Gender dan Strategi Pengarus-utamaannya di Indonesia..., h. 
perempuan. Terlebih-lebih jika si perempuan tersebut harus bekerja, maka ia memikul beban kerja ganda. ${ }^{10}$

\section{Konsep Keadilan Gender}

Islam memberikan keadilan gender sebagaimana tertera dalam Al-Qur'an surat An-Nahl ayat 97 yang artinya "Barang siapa yang mengerjakan amal shalih baik laki-laki maupun perempuan dalam keadaan beriman maka pasti akan Kami berikan padanya kehidupan yang baik dan akan Kami beri balasan dengan pahala yang lebih baik dari apa yang telah mereka kerjakan." Allah tidak memandang laki-laki dan perempuan, jika mereka melakukan kebaikan sementara tetap beriman maka balasan Allah sungguh sangat besar. Beramal shalih bisa bermacam-macam bentuknya sesuai dengan kadar kemampuan. Jika laki-laki jihadnya berperang di jalan Allah dan mencari nafkah, maka perempuan berjihad saat melahirkan dan mengasuh anakanaknya.

Terwujudnya keadilan gender ditandai dengan tidak adanya diskriminasi antara perempuan dan laki-laki, dan dengan demikian mereka memiliki akses, kesempatan berpartisipasi, kontrol atas pembangunan dan memperoleh manfaat yang setara dan adil dari pembangunan. ${ }^{11}$ Adapun indikator keadilan gender adalah sebagai berikut: (a) Akses yaitu peluang atau kesempatan dalam memperoleh atau menggunakan sumber daya tertentu. Mempertimbangkan bagaimana memperoleh akses yang adil dan setara antara perempuan dan laki-laki, anak perempuan dan laki-laki terhadap sumberdaya yang akan dibuat; (b) Partisipasi yaitu keikutsertaan atau partisipasi seseorang atau kelompok dalam kegiatan atau dalam pengambilan keputusan; (c) Kontrol yaitu penguasaan atau wewenang atau kekuatan untuk mengambil keputusan; (d) Manfaat yaitu kegunaan yang dapat dinikmati secara optimal.

10 Mansour Fakih, Analisis Gender dan Transformasi Sosial, (Yogyakarta: Pustaka Pelajar, 1999), h. 21

11 Mansour Fakih, Analisis Gender dan Transformasi Sosial... h. 29 


\section{Bentuk Implementasi keadilan Gender dalam Pendidikan Pesantren}

Secara umum, pembelajaran pada asrama putra dan asrama putri di pesantren sama, pengajian kitab kuning sesuai dengan tingkat usia dan kematangan berfikir para santri. Misalnya kitab Ta'lim alMuta'alim, Matanahwu suja', Imriti, Riyad al-Shalihin, Wasoya, Arbain Nawawi, dan berganti-ganti kitab diseputar tasawuf dan fikih. Namun masalah kesamaan akses, pesantren masih memberlakukan kebijakan yang berbeda. Misalnya peraturan tentang boleh tidaknya santriwati mengaji di luar asrama. Bahwa akses untuk mendapatkan tambahan pengetahuan melalui pengajian-pengajian kitab di luar asrama berbeda antara santriwan dan santriwati. Yang menjadi pertimbangan berbedanya akses untuk mengikuti kegiatan di luar asrama adalah untuk memelihara tradisi pesantren, menjaga kehormatan dan martabat santriwati.

Dibukanya akses yang sama antara santriwan dan santriwati akan memudahkan mereka saling bertemu di khawatirkan menimbulkan fitnah. Dengan demikian santriwati cukup belajar sesuai dengan jadwal kegiatan pembelajaran di asrama yang dibimbing oleh nyai dan ustadzah yang memiliki kapasitas keilmuan terbatas. Karena itu tidaklah heran jika terjadi kesenjangan penguasaan kitab kuning antara santriwan dan santriwati akibat dari sistem kebijakan pesantren. Berbeda dengan santriwan mereka memiliki akses yang cukup longgar mengaji kitab kuning kepada ustad-ustad yang berdomisili di luar asrama.

Dalam aspek kontrol sumber daya, partisipasi santriwati juga masih lebih sedikit dibanding santriwan. Kegiatan yang dilaksanakan seperti "bahtsul masail" yaitu forum yang dibuat pesantren untuk membahas masalah-masalah yang muncul dikalangan masyarakat baik masalah agama juga masalah sosial yang aktual tetapi belum ada hukum dan dalilnya dalam agama. Peserta "bahtsul masa'il" terdiri dari para santriwan, kyai sebagai nara sumber dan ustadz sebagai moderator. Dalam forum bahtsul masail (musyawarah hukum) santriwati tidak diikutsertakan. Mereka hanya menerima apa yang 
menjadi keputusan bahtsul masail santriwan tanpa mengetahui bagaimana proses jalannya kegiatan.

Dengan keadaan demikian semakin menegaskan minimnya kemampuan santriwati dalam kitab kuning dari pada santriwan. Selain itu, terdapat pula materi pelajaran yang tidak diberikan kepada santriwati namun diberikan kepada santriwan. Santriwan mendapatkan pelajaran IImu Falak, maka tidak demikian dengan santriwati. Alasannya Ilmu Falak tidak penting bagi santriwati karena ada keilmuan yang dianggap lebih penting untuk dipelajari bagi santriwati yaitu kitab Risalatul Mahid, suatu kitab yang membahas tentang menstruasi dan permasalahannya.

Perbedaan semakin tampak ketika santriwan mendapatkan pelajaran dalam bentuk diklat, namun tidak demikian bagi santriwati. Meskipun santriwan dan santriwati diberikan akses yang sama untuk mengikuti organisasi santri namun masih terjadi kesenjangan dalam aspek kontrol sumber daya. Dalam rapat-rapat gabungan yang membicarakan agenda besar pesantren seperti haul mengundang instansi lain dan keluarga besar pondok pesantren yang diwarnai dengan pembacaan doa, tahlil dan solawat serta pengajian dan hiburan islami, santriwan memiliki kepercayaan dan tanggung jawab yang lebih tinggi dari pada santriwati. Pendapat santriwan lebih didengarkan dari pada santriwati. Forum gabungan seakan menjadi diskusi yang terpusat pada pemikiran santriwan, sementara satriwati hanya sebagai pendukung dan pelengkap saja.

Selanjutnya, setiap tahun dibentuk kepanitiaan yang khusus mengurus acara haul. Namun dalam pengambilan peran posisi santriwati masih berada di bawah santriwan. Santriwan mendapat tugas sebagai koordinator, ketua, seksi publikasi dan juga bendahara. Sedangkan santriwati hanya mendapat tugas-tugas yang berhubungan dengan tamu, seperti penerima tamu, mengurusi konsumsi, menyiapkan hiasan dekorasi, serta membersihkan lingkungan pesantren. Pembagian peran yang berbeda ini seolah memisahkan bahwa santriwan mendapat peran-peran publik sedangkan putri mendapat peran domestik. 
Santriwan dan santriwati diberikan akses untuk mengikuti pelatihan muhadoroh di pesantren namun manfaat yang mereka terima dalam kegiatan ini masih berbeda antara santriwan dan santriwati. Kebiasaan pengasuh yang mengirimkan santriwan senior untuk mengisi pengajian di daerah sekitar pesantren. Santri yang dikirim ke daerah tersebut umumnya didominasi oleh santriwan karena dirasa lebih aman dari pada mengirim santriwati, di samping selama ini banyak masyarakat yang meminta penceramah laki-laki, kecuali untuk pengajian khusus ibu-ibu atau anak-anak. Hal tersebut menunjukkan bahwa peran perempuan dalam kegiatan sosial religius dianggap hanya berhubungan dengan aktivitas yang lebih sederhana, bersifat domestik dan lebih mementingkan unsur keperempuanan. Kegiatan yang bersifat massal dan yang lebih bergengsi dianggap sebagai wilayah laki-laki.

Setiap ada kegiatan seperti perpisahan dan haul yang ditampilkan untuk mengisi acara adalah kelompok hadroh dari santriwan. Sehingga santriwati jarang mendapat kesempatan untuk tampil dalam acara yang sama. Hadroh putra juga sering diikutsertakan dalam agenda karnaval dan festival. Pada acara pengajian rutin pengisi acara rata-rata yang diambil perannya santriwan bahkan santriwati sama sekali tidak diberi porsi untuk turut meramaikan acara pengajian. Mulai dari kyai sebagai pembuka acara, kemudian santriwan juga yang membaca tilawah Al- quran bahkan pengisi acara seni juga yang ditugaskan adalah kelompok hadroh santriwan. Disisi lain santriwati pun juga memiliki kelompok hadroh, namun kelompok santriwati tidak mendapat kesempatan yang sama untuk memeriahkan acara pengajian. Secara tidak langsung hal ini menyiratkan bahwa panggung adalah milik laki-laki. Kultur patriarkhi ini semakin nampak ketika pesantren mengundang alumni santriwan untuk mengisi pengajian. Jarang didapati pesantren mengundang alumni santriwati untuk mengisi dalam pengajian. 


\section{Gender dalam "catatan" Culture Nature}

Perempuan dianggap sebagai sosok yang rawan dan lemah sehingga akses untuk ke luar harus dibatasi sebagai upaya untuk melindungi perempuan itu sendiri. Hal tersebut seperti yang diungkapkan oleh Deaux dan Kite dalam Partini bahwa gender didukung oleh sistem kepercayaan gender (gender belief system).12 Dalam bukunya Bias Gender dan Birokrasi, Partini juga menyebutkan pendapat Deaux dan Kite, bahwa sistem kepercayaan gender mencakup elemen diskriptif, yaitu kepercayaan tentang bagaimana "sebenarnya" laki-laki dan perempuan, serta bagaimana "seharusnya" laki laki dan perempuan bersikap.

Adanya semacam sistem kepercayaan gender yang sudah terbangun di pesantren, sebagai wujud dari sistem kepercayaan gender tersebut munculah aturan tentang bagaimana santriwan dan santriwati harus berperilaku dan bersikap. Pada santriwan diberi kelonggaran untuk mengaji di luar pesantren karena dianggap sebagai sosok yang kuat dan bisa melindungi dirinya sendiri, sedangkan santriwati dianggap sebagai sosok yang lemah maka harus dijaga oleh yang lebih kuat. Dampaknya santriwati cukup mengaji kitab di pondok pesantren saja sesuai dengan jadwal yang sudah ditentukan.

Adapun dampaknya pengalaman dunia luar pesantren yang didapat santriwan lebih banyak dibanding santriwati. Dari penjelasan di atas mengenai perbedaan akses yang didapat oleh santriwan dan santriwati menunjukkan bahwa terjadinya keunggulan laki-laki terhadap perempuan karena dikonstruksi oleh budaya yang di pengaruhi oleh peluang laki-laki yang lebih besar untuk berperan aktif terhadap dunia luar. Menurut Abdullah laki-laki yang memiliki akses yang lebih besar terhadap sektor produktif kemudian dikonstruksikan untuk berperan sosial di sektor publik, sedangkan perempuan mempunyai tugas mulia 4 " $\mathrm{M}$ " (menstruasi, mengandung, melahirkan, dan menyusui) dikonstruksikan untuk berperan di sektor "sosial

12 Partini, Bias Gender dalam Birokrasi, (Yogyakarta: Tiara Wacana. 2013). h. 
domestik", yaitu menguasai rumah tangga, anak dan melayani lakilaki (suami). Perempuan yang baik dipresentasikan sebagai ibu maupun istri yang terkait dengan rumah, anak, masakan, pakaian, kecantikan, kelembutan, dan keindahan. ${ }^{13}$

Sementara itu, menurut Achmad dalam Partini ideologi gender merupakan ideologi yang mengkotak-kotakkan peran dan posisi ideal perempuan didalam rumah tangga dan masyarakat. Peran ideal inilah yang akhirnya menjadi sesuatu yang aku dan stereotip. Ideologi gender sering kali menyudutkan perempuan dalam konteks kefeminimannya, sehingga yang di lakukan perempuan hanyalah untuk memantaskan diri sebagaimana telah di gariskan sesuai dengan kodrat dan stereotip yang sudah menjadi hal yang baku di dalam masyarakat. ${ }^{14}$ Stereotipe gender dapat dilihat dari adanya kegiatan yang disebut dengan "Bahtsul Masail". Bahtsul masail merupakan forum yang diadakan oleh pesantren untuk membahas masalahmasalah yang muncul di kalangan masyarakat yang belum ada hukum dan dalilnya dalam agama.

Jadi bahtsul masail dapat di katakan sebagai musyawarah hukum mengenai masalah sosial. Namun dalam forum ini santriwati tidak diikutsertakan. Mereka hanya menerima apa yang menjadi keputusan bahtsul masail yang dilakukan santriwan bersama ustadz dan kyai sehingga santriwati tidak mengetahui bagaimana proses jalannya kegiatan. Hal ini secara tidak langsung semakin menandaskan bahwa kemampuan santriwati dalam menguasai kitab kuning diragukan.

Sehingga persepsi yang terbangun bahwa ranah berpikir adalah ranah yang pantas dipegang oleh laki-laki, yang dianggap sebagai pribadi yang cocok sebagai pengambil keputusan karena mempunyai pemikiran logis, sebaliknya sosok santriwati diibaratkan sebagai sosok yang kurang kompeten dalam ranah berfikir sehingga 2006), h.7

13 Irwan Abdullah, Sangkan Paran Gender, (Yogyakarta: Pustaka Pelajar, 14 Partini, Bias Gender dalam Birokrasi, (Yogyakarta: Tiara Wacana. 2013), h. 17 
tidak diikutsertakan. Adanya kebijakan santriwati hanya menerima apa yang menjadi keputusan musyawarah hukum (bahtsul masail) dari santriwan semakin menguatkan lemahnya kontrol terhadap sumber daya di pesantren oleh santriwati.

Menurut Abdullah di dalam tatanan sosial yang dilandasi pada sistem hubungan yang patriarkis, segala kegiatan perempuan dan persepsi masyarakat terhadap status dan posisi perempuan, di lingkupi oleh nilai-nilai yang memihak kepada pria. Nilai-nilai yang patriarkis tersebut diinternalisasikan dan dilanggengkan melalui berbagai institusi sosial seperti lembaga politik, pendidikan, maupun kepercayaan-kepercayaan, sehingga subordinasi tersebut tidak dirasakan sebagai suatu sistem yang secara langsung sangat menekan dan memojokkan perempuan. ${ }^{15}$ Sama halnya dengan santriwati yang merasa bahwa pemberian materi berbeda adalah suatu kewajaran karena santriwati sudah menginternalisasi kepercayaankepercayaan yaitu mempelajari hal-hal yang berkaitan dengan kodratnya (menstruasi) adalah cukup. Sehingga santriwati tidak merasakan adanya posisi penomorduaan dibanding santriwan.

Meskipun keduanya diberikan akses yang sama untuk mengikuti organisasi santri namun masih terjadi kesenjangan dalam aspek kontrol sumber daya. Menurut Hartman dalam Partini pada sistem patriarki, laki-laki mengontrol kerja perempuan, baik di dalam maupun di luar rumah. ${ }^{16}$ Abdullah menjelaskan bahwa implikasi dari perbedaan nature dan culture tersebut adalah terjadinya pemisahan sektor kehidupan. Perempuan yang diidentifikasikan sebagai "nature", dianggap sebagai orang yang berkaitan erat dengan sektor domestik. Sedangkan laki-laki di tempatkan sebagai kelompok yang berhak mengisi sektor publik. Ideologi semacam ini telah disahkan oleh berbagai pranata dan lembaga sosial, yang kemudian menjadi fakta sosial tentang status-status dan peran-peran yang dimainkan oleh 2006) h. 84

15 Irwan Abdullah, Sangkan Paran Gender, (Yogyakarta: Pustaka Pelajar, 16 Partini, Bias Gender dalam Birokrasi..., h. 15 
perempuan. ${ }^{17}$ Meskipun sama-sama diberikan akses untuk mengikuti organisasi santri namun kesenjangan peran yang di dapatkan santriwan dan santriwati masih terlihat. Bahwa di setiap akhir tahun ada agenda rutin yang digelar pesantren seperti haul. Dalam acara tersebut pondok mengundang instansi lain yang hadir memeriahkan haul yang diwarnai dengan rangkaian acara doa, tahlil, sholawat serta pengajian dan hiburan islami. Dalam kepanitiaan khusus untuk mengurus acara ini pengambilan peran dan posisi santriwati masih berada di bawah santriwan. Pembagian peran yang berbeda ini seolah menempatkan bahwa santriwan pantas mendapat peran-peran publik sedangkan santriwati mendapatkan peran domestik. Alison Scott dalam Saptari \& Holzner, menyebutkan bahwa ada 3 bentuk marginalisasi, (1) sebagai proses pengucilan (exlusion), (2) sebagai proses pergeseran perempuan ke pinggiran (margins), (3) sebagai proses feminisasi atau segregasi. ${ }^{18}$ Adapun yang di alami oleh para santriwati adalah bentuk dari proses feminisasi, dimana dalam bentuk ini adanya pemusatan tenaga kerja perempuan ke dalam jenis-jenis pekerjaan tertentu, bisa dikatakan bahwa jenis-jenis pekerjaan tersebut sudah ter-"feminisasi" (dilakukan semata-mata oleh perempuan).

Abdullah menyatakan keberadaan perempuan selalu menjadi yang nomor dua dan di bawah laki-laki. Peran dan status perempuan juga tidak terlalu diperhitungkan. Terdapat dikotomi nature dan culture yang digunakan untuk menunjukkan pemisahan dan stratifikasi di antara dua jenis kelamin ini. Perempuan mewakili sifat "alam" (nature) harus di tundukkan agar mereka lebih berbudaya (culture). Usaha membudayakan perempuan tersebut menyebabkan terjadinya proses produksi dan reproduksi ketimpangan hubungan antara laki-laki dan perempuan. ${ }^{19}$

\footnotetext{
17 Irwan Abdullah, Sangkan Paran Gender..., h. 4

18 Ratna Saptari, Perempuan Kerja dan Perubahan Sosial, (Jakarta: Pustaka Utama Grafiti, 1997), h. 8

19 Irwan Abdullah, Sangkan Paran Gender, (Yogyakarta: Pustaka Pelajar. 2006) h. 3
} 
Ketimpangan hubungan yang memisahkan perempuan mewakili hal-hal domestik sedangkan laki-laki mewakili ranah publik juga terlihat dalam kegiatan non akademik muhadoroh. Sekilas terlihat bahwa pondok memberikan akses bagi santri putra dan putri untuk mengikuti kegiatan muhadoroh. Muhadoroh merupakan kegiatan latihan berdakwah yang diadakan rutin satu minggu sekali. Latihan muhadoroh ini dimaksudkan guna mempersiapkan santri untuk terjun di masyarakat. Meskipun keduanya diberikan kesempatan untuk berlatih muhadoroh namun manfaat yang mereka terima dalam kegiatan ini masih berbeda antara santriwan dan santriwati.

Kebiasaan pengasuh yang mengirimkan santri putra senior untuk mengisi pengajian di daerah sekitar. Santri yang dikirim ke daerah umumnya di dominasi oleh putra karena dirasa lebih aman dari pada mengirim santri putri, di samping selama ini memang banyak masyarakat yang meminta penceramah laki laki, kecuali untuk pengajian khusus ibu-ibu dan anak-anak. Hal tersebut menunjukkan bahwa domestifikasi peran perempuan dalam kegiatan sosial religius masih ada.

\section{E. Kesimpulan}

Keadilan gender dalam pendidikan Islam di pondok pesantren belum dilakukan secara optimal. Meskipun secara umum santriwan dan santriwati diberikan hak pendidikan Islam yang sama di bidang akademik yang terfokus pada kajian kitab kuning serta non akademik yang terfokus pada kegiatan organisasi intra pesantren, muhadoroh (dakwah) serta hadroh (seni rebana), namun masih terjadi perbedaan akses, partisipasi, kontrol terhadap sumber daya serta manfaat yang diperoleh dari proses pendidikan Islam di pesantren.

Belum optimalnya keadilan gender dalam pendidikan Islam di pondok pesantren dikarenakan kendala kultural yang mengakibatkan adanya kebijakan kurang responsif gender. Kendala kultural yang dimaksud yaitu sistem patriarki. Pada sistem patriarki laki-laki mengontrol kerja perempuan. Kebudayaan yang dimotori oleh budaya patriarki menafsirkan perbedaan biologis menjadi indikator 
kepantasan dalam berperilaku yang akhirnya berujung pada pembatasan hak, akses, partisipasi, kontrol dan menikmati manfaat dari sumber daya dan informasi. Akhirnya tuntutan peran, tugas, kedudukan dan kewajiban yang pantas dilakukan oleh laki-laki atau perempuan dan yang tidak pantas dilakukan oleh laki-laki atau perempuan sangat bervariasi.[]

\section{Daftar Pustaka}

Mufidah, Gender di Pesantren Salaf Why Not ? Malang: UIN-Maliki Press, 2010

Saptari, Ratna. Perempuan Kerja dan Perubahan Sosial, Jakarta: Pustaka Utama Grafiti, 1997.

Abdullah, Irwan. Sangkan Paran Gender, Yogyakarta: Pustaka Pelajar, 2006.

Partini, Bias Gender dalam Birokrasi, Yogyakarta: Tiara Wacana, 2013.

Fakih, Mansour. Analisis Gender dan Transformasi Sosial. Yogyakarta: Pustaka Pelajar, 1999.

Nugroho, Rian. Gender dan strategi pengarus-utamaannya di Indonesia, Yogyakarta: Pustaka Pelajar, 2008.

Djunaedi, Wawan. Pendidikan IslamIslam Adil Gender di Madrasah. Jakarta: Pustaka STAINU, 2008.

Rosaldo, Louis. Woman, Culture and Society, California: Satndford University Press, 1974.

Mosse, J.C. Gender \& Pembangunan. Yogyakarta: Pustaka Pelajar, 2007.

Salim, Agus. Teori dan Paradigma Penelitian Sosial. Yogyakarta: Tiara Wacana yogya, 2001.

Sutopo, H.B. Metodologi Penelitian Kualitatif: dasar teori dan terapannya dalam penelitian. Surakarta: UNS Press, 2002.

Gunawan, I. Metode Penelitian Kualitatif: Teori \& Praktik. Jakarta: Bumi Aksa, 2014. 